\title{
Capitalism without capital: the rise of the intangible economy
}

JONATHAN HASKEL and STIAN WESTLAKE, Princeton University Press, 2018, 278 pp.

Book review by DUBRAVKO MIHALJEK*

https://doi.org/10.3326/pse.44.1.5

\footnotetext{
"Received: October 13, 2019

Accepted: October 29, 2019

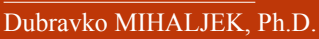

Bank for International Settlements, Centralbahnplatz 2, 4002 Basel, Switzerland e-mail: Dubravko.Mihaljek@bis.org ORCiD: 0000-0003-4706-9534
} 
This book by and large meets the high expectations raised by its catchy title: it provides important insights on the evolution of capitalism in the global economy during the first two decades of the 21 st century. The concept of intangible capital - computerised information, innovative property and economic competencies helps explain developments as diverse as the long-term decline in business fixed investment, low measured productivity growth, the rise of giant technology firms, the shift in financial intermediation from banks to markets, and the growth of inequality. The book is broad in coverage yet is focussed on the core theme; it is wellarticulated and informative for economists as well as other social scientists and non-specialists. And importantly, it provides sound and insightful policy advice.

Unlike the technological breakthroughs of the past century - for instance in transportation and telecommunications, electricity generation and use, new materials, agriculture, medicine - digital technologies are largely disembodied. Computer software, databases, product and service designs, organisational skills and business processes take no physical form. This "intangible" character of much of today's capital, in contrast to machines, factory buildings, power plants, laboratories, scientific equipment and so on, is important because, as Haskel and Westlake argue, it changes the way that the market economy works.

To get to that big picture, Jonathan Haskel and Stian Westlake begin by discussing what intangible capital is and what its special properties are. ${ }^{1}$ The first studies on the contribution of different types of knowledge to economic output date back to the early 1960s. At the time, economists such as Fritz Machlup and Zvi Griliches began to measure expenditure on $R \& D$ and started to question the then established view that research and development $(\mathrm{R} \& \mathrm{D})$, product design, training, branding and the like were an intermediate input.

The next step in understanding the role of intangible capital was to account for the contribution of computer hardware and software in investment statistics. The first task faced an immediate challenge: the price of hardware has to be properly adjusted for quality improvements. Otherwise, the tendency for computer prices to fall over time results in an erroneous conclusion that spending on computer hardware accounts for a declining proportion of total investment. It took almost 20 years, starting in the early 1980 s, for this adjustment to be properly implemented by statistical agencies, first in western Europe and then in the United States.

That was followed by accounting for software. Many companies and institutions write their own computer codes, which represent a long-lasting form of knowledge that has no tangible form. Citibank, for instance, once employed more programmers than Microsoft (p. 40). While both economists and statisticians

\footnotetext{
${ }^{1}$ Jonathan Haskel is professor of economics at Imperial College Business School in London, and since September 2018 an external member of the Bank of England's Monetary Policy Committee, a body that sets policy interest rates in the United Kingdom. Stian Westlake is Executive Director of Policy and Research at Nesta, a UK research foundation focusing on innovation.
} 
concluded that software ought to be treated like an investment, the problem was that there was no place for software on various investment surveys that statistical agencies asked firms to fill out. Again, it took several years to implement this change. The US Bureau of Economic Analysis started counting expenditure on software as part of investment spending in 1999, followed by the UK statistical authorities in 2001.

In a pioneering work on the measurement of intangible capital, Corrado, Hulten and Sichel (2005) defined three broad categories of intangible investment: computerised information, innovative property, and economic competencies. ${ }^{2}$ Computerised information includes investment such as purchasing software, writing own software, and developing and maintaining databases. Innovative property covers investment spending on $\mathrm{R} \& \mathrm{D}$, mineral exploration, creating entertainment and artistic originals, and design and other product development costs. Economic competencies include other expenditure that does not directly involve innovation or computers: training of staff (i.e., investment in a company's human capital); marketing and branding (i.e., investment in understanding customer needs); and spending on organisational capital (i.e., re-engineering of business processes) that creates distinctive business models or corporate cultures. Statistical agencies around the world have gradually taken over this categorisation of intangible investment. In the United States, the first to implement it fully, capitalisation of software added about $1.1 \%$ to the 1999 GDP, while R\&D added $2.5 \%$ to the 2012 GDP. Investment in intangible capital is already estimated to exceed that in tangible capital in Finland, Ireland, the United States, Sweden and the United Kingdom.

An important contribution of the book is a discussion in Chapter 4 of the distinguishing characteristics of intangible investment. Haskel and Westlake propose four such characteristics: scalability, sunkenness, spillovers, and synergies. The first of the four S's, scalability, stems from the non-rival nature of intangible assets. For instance, once a company has developed its human resources management software, it can use it in multiple locations at the same time without any additional cost. By contrast, physical assets such as trucks can only be used in one place at one time: they are not scalable the way intangible capital is.

The second feature is that the cost of developing intangible capital is largely irrecoverable or "sunk". For instance, an airline company that developed its own software for flight reservations is unlikely to find a buyer for that system if it goes out of business. That contrasts with tangible assets such as delivery vehicles, which can be sold off to recover partly the initial investment costs.

Intangible investments by one firm also tend to have large spillovers to other firms. Unless protected by comprehensive patents, the benefits from R\&D

${ }^{2}$ See Corrado, C., Hulten, C. and Sichel, D., 2005. Measuring capital and technology: an expanded framework in: C. Corrado, J. Haltiwanger and D. Sichel, eds. Measuring capital in the new economy. Chicago: University of Chicago Press, pp. 11-46. 
investment and software development - not to mention innovations in business organisation, training and branding of products and services - also tend to benefit firms that did not pay for such investment. While this may also be the case with investments in some physical assets, e.g., in transportation infrastructure, it is easier to establish property and usage rights over tangible assets than intangibles. In fact, as Haskel and Westlake remind us, much of the legal system and institutional history is based on the establishment of property rights over capital assets.

Intangible investments also exhibit synergies with one another - e.g., hardware with software - and with tangible investments - e.g., computers and software have dramatically increased productivity and investment in warehousing and distribution of goods and services since the 1990s. As Haskel and Westlake explain, such synergies matter because they create incentives to bring together different intangibles, especially new ideas. This encourages openness and sharing rather than appropriation of knowledge. At the same time, it encourages firms to protect their intangible investments against competition - not by protecting individual assets (e.g., through patents), but by creating clusters of intangibles, for instance mobile phone operating systems, data bases, streaming services and so on.

These four distinguishing characteristics of intangible capital have some important consequences for the development of the central thesis of the book, that the growing proportion of intangible capital in total investment changes the way the market economy functions. Most of the book - Chapters 5-11 - is devoted to the analysis of some of these consequences. Only a few are noted here.

Perhaps the easiest to understand is the impact of intangible capital on market competition. Scalability enables successful companies in an intangible-rich economy to grow very fast and expand globally. With their superior technology and integrated business processes, successful tech firms can create major obstacles to the competition of incumbent and entry of new firms. This may affect the competitive structure of some industries - retail, travel agencies, and taxi services are just some of the more recent examples.

Although intangible-rich companies may on their own invest huge amounts in $\mathrm{R} \& \mathrm{D}$, productivity growth in the entire economy may stagnate. The reason is that potential competitors may be discouraged from entering a market in which a few dominant firms already have a technological and competitive edge - for instance, a more powerful internet search engine. Leading firms can easily overtake their competitors by scaling up on their intangible assets, and by assimilating knowledge through acquisition of potential rivals, often start-ups. This may result in a growing gap between leading ("frontier") and lagging firms and, in aggregate, a slower productivity growth in the economy. This explanation, developed in Chapter 5, provides an interesting angle on the debate on so-called secular stagnation, a hypothesis that we live in a period of permanently slower total factor productivity growth. 
The four S's of intangible capital also imply that intangible-rich companies are not confined to a specific location. They can shift their operations globally, according, for example, to the tax treatment they receive in a given location. This may create unhealthy tax competition among cities, regions and countries vying to attract successful tech companies, not to mention any resulting revenue losses. It also means that more resources than otherwise may be wasted on unproductive lobbying and rent-seeking activities.

There are important consequences of intangibles for the rise of inequality as well. As discussed in Chapter 6, the synergies and spillovers that intangibles create make it easier for intangibles-rich companies to attract talent with the education and skills needed to work in knowledge-based industries, and to pay them higher wages. Recent research suggests that such inter-firm differences can explain a significant proportion of the rise in income inequality. In addition, the rise of intangible industries makes cities with network externalities increasingly attractive places to live and work in. Given the limited supply of land for development in most urban centres, rising demand for housing inevitably drives up property prices. And as housing is the main form of wealth for most families, house price inflation is one of the key determinants for growing wealth inequality.

No less important are the consequences of intangible capital for investment financing, elaborated in Chapter 8. Traditional ways of funding business investment borrowing from banks and issuing bonds in corporate debt markets - are not suitable for financing intangible investments. The reason is that such capital does not have the properties of traditional collateral: it is not tangible (unless protected by copyright or patents) so creditors cannot seize and sell it to recoup losses if the borrower can't repay the loan or make payments on the bond it issued. This implies that much of intangible capital has to be financed by issuing equity, or from a firm's retained earnings. Buyers of intangible firms' equity are unlikely to be traditional ones, retail or institutional investors, but rather specialised investment and venture capital funds. This, in turn, has consequences for the way intangible-rich firms are managed as well as for their growth and life cycle.

What does all this imply for public policy? Haskel and Westlake examine five questions in Chapter 10 that they see as most challenging for policymakers in an intangible-rich economy. The first one is how to develop a "good" intellectual property rights framework for intangible capital. As noted above, it is hard to prove who owns intangibles, and even then, their benefits tend to spill over to many users. The second one is how to maximise the benefits of synergies associated with intangible capital. In particular, how to devise urban land use rules, and plan and develop physical infrastructure in cities so as to create the best possible conditions for knowledge and innovative ideas to spread easily. The third challenge is how to facilitate the financing of an intangible economy, in particular the shift from debt to equity financing. A core issue is the tax treatment of debt: tax systems around the world allow companies to claim tax relief on interest 
payments but not on the cost of equity. The fourth policy challenge is how to encourage more investment in intangibles. What combination of favourable conditions for private investment on the one hand, and public investment on the other - public R\&D funding, public procurement, training and education - will help knowledge-based, intangible-rich activities to spread? And finally, how is one to cope with the income and wealth inequality associated with the rise of intangible economy?

Haskel and Westlake develop a number of policy proposals to tackle these five challenges. They are not only embedded in sound economic analysis and supported by empirical findings, but also make good common sense. Particularly illuminating is the comparison of policy approaches in two fictional countries in Chapter 9. Not surprisingly, one feature that makes a big difference in how countries cope with the challenges of intangible economy is social capital. Trust and social cohesion make it easier for ideas to spread around the economy through social networks. They also make it politically more feasible to mitigate the consequences of rising inequality through government policy. Where social cohesion is weak and mistrust of institutions and other social groups is widespread, the growing importance of intangibles often leads to economic pressures. Those pressures, in turn, exacerbate the political divides driving today's populist movements. 